\title{
Influence of Temperature on Microstructure and Oil Content in Vacuum Frying of Fish Tofu
}

\author{
Thiwari Ophithakorn ${ }^{1}$ and Sutisa Yaeed $^{2}$
}

\begin{abstract}
Vacuum frying is a new cooking technique that can be developed to reduce the oil content in food. In this study, atmospheric frying $\left(165{ }^{\circ} \mathrm{C}\right)$ and vacuum frying $\left(120^{\circ} \mathrm{C}\right.$ at $21 \mathrm{kPa}$ ) conditions were observed in fish tofu. High temperature affected the structure and oil content in the atmospheric frying process. The high surface temperature of the fish tofu in the atmospheric frying condition caused microstructure destruction. Oil uptake increased due to adsorption into the product surface that resulted in the collapse and change of the porosity. In contrast, vacuum frying can be used to reduce final oil content and preserve the microstructure of the fish tofu while the moisture content was lost. The results of frying under vacuum conditions produced a high quality fish tofu.
\end{abstract}

Keywords - vacuum frying, fish tofu, oil content, moisture content, microstructure.

\section{INTRODUCTION}

Surimi is used as the raw fish material for a variety of products. Fish tofu is the highest value-added product from surimi and is one of the most popular products with consumers in Thailand.

Deep-fat frying is the major process of cooking fish tofu in the food industry. Many factors contribute to the frying process: temperature, warm-up time, type of oil, size and nature of the product [1]. Other factors are heat, mass transfer, and chemical change such as starch gelatinization, protein denaturation, surface browning and color changes of the product, water evaporation, oil absorption, crust and crunch layer formation, shrinkage and expansion, hydrolysis of frying fats, and interaction between food constituents and oxidized lipids $[1,2]$. The frying process presents a significant increase in the oil content of the product [3] because this process uses immersion of food in hot oil that can evaporate the water and replace it with absorbed oil in the product [4].

\footnotetext{
${ }^{1}$ Innovation and Management College, Songkhla Rajabhat University Satun Campus, Songkhla Rajabhat University, Muang, Songkhla, 90000, Thailand

${ }^{2}$ Faculty of Environmental Management, Prince of Songkla University, Hat Yai, Songkhla, 90112, Thailand
}

Recent consumer trends are for healthier food consumption. They are the key growth factors for alternative products that are low in oil, low in fat, and promote health benefits [5-7]. Oil content affects product acceptability by the consumers [2]. The vacuum frying process produces a product with lower oil content, natural color, good flavor, minimal loss of vitamins and minerals, less effect on characteristic texture, less effect on frying oil quality, and a lower level of carcinogenic neurotoxins due to decreased levels of acrylamide [7-15]. Therefore, the vacuum frying process was developed as an alternative technique to produce healthier products and can be used in various fried food products, such as bananas, carrots, apples, potatoes, mangos, green beans, guava, and gilthead sea bream $[3,5,7-13,15]$. Several companies in Asia use vacuum frying for fruits, vegetables, and fish and shellfish products [7].

Therefore the development of vacuum frying is an important alternative cooking method for human health and fish tofu consumption in the future. The objective of this research was to investigate the influence of vacuum frying conditions on the moisture loss and oil content during the frying time.

\section{MATERIALS AND METHODS}

\section{A. Sample Preparation and Storage Conditions}

Steamed fish tofu $(2.5 \mathrm{~cm} \times 2.5 \mathrm{~cm} \times 3.0 \mathrm{~cm}$. $)$ was used as the raw material in this study. The size of the products was controlled because size has a significant effect on the moisture content during frying [1]. The steamed fish tofu was kept in vacuum polyethylene bags and frozen at $-20{ }^{\circ} \mathrm{C}$ until defrosting and defrosted at $4{ }^{\circ} \mathrm{C}$ overnight in a refrigerator before use.

\section{B. Vacuum Fryer}

The vacuum frying system is illustrated in Fig. 1. This system consisted of a $35 \mathrm{~L}$ stainless steel vessel, frying basket, condenser, vacuum pump, temperature controller, and gas fire system. Frying samples could move up and down into the heated oil. The condenser condensed oil and water vapors before air flowed in the vacuum pump. The laboratory scale equipment was set up in the Department of Chemical Engineering, Prince of Songkla University, Hat Yai, Thailand. 


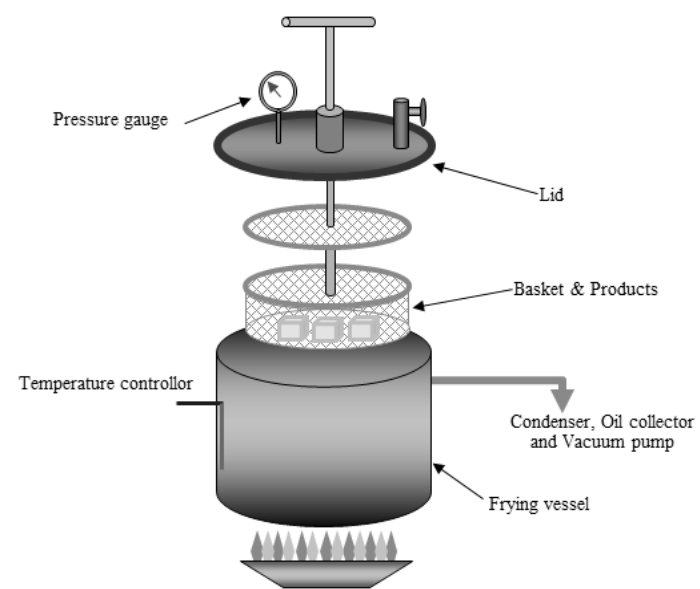

Fig. 1: Vacuum frying system (modified [16])

\section{Frying Experiments}

For the atmospheric frying condition, the steamed fish tofu was fried in the vessel while the lid was open. The frying temperature $\left(165{ }^{\circ} \mathrm{C}\right)$ and frying time $(150 \mathrm{sec})$ were controlled according to industry standard conditions. The conditions for vacuum frying were $120{ }^{\circ} \mathrm{C}$ at $21 \mathrm{kPa}$. In other conditions, the fish tofu bloated at lower vacuum pressures or higher frying temperatures. That was possibly caused by the puffing phenomenon that came from the closing of pores and greater pressure from the expansion of gases inside the fish tofu [13].

The soybean oil $(12 \mathrm{~L})$ was preheated and approximately 8 pieces of steamed fish tofu (about $160 \mathrm{~g}$ per batch) were fried in deep oil for $150 \mathrm{sec}$. After frying, all samples were centrifuged at $450 \mathrm{rpm}$ for $120 \mathrm{sec}$ to remove the surface oil. Centrifugation reduced the oil uptake in both atmospheric and vacuum frying conditions $[2,14,17]$. In the vacuum frying condition, the lid was fastened, air in the vessel was evacuated, and the steamed fish tofu inside the basket was immersed in the heated oil.

The moisture contents of the initial product and fried products were measured by keeping $2 \mathrm{~g}$ of product at $60{ }^{\circ} \mathrm{C}$ for

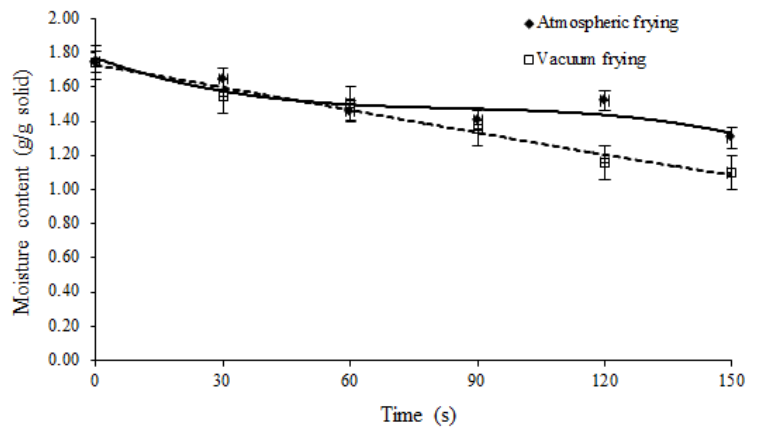

Fig. 2: Moisture content and oil content of fish tofu in atmospheric and vacuum frying conditions

Previous studies reported that in the vacuum frying of fruits and vegetables there was no significant initial fat content but fish or sea food showed variability in the initial fat content of the samples [3]. Oil absorption was significantly lower in the vacuum fried condition because oil was obstructed by faster diffusion of air into the porous product [14]. Moreover, structural changes occurred at the initial depressurization step
4 hours (to constant mass) in a vacuum oven, and cooled in a desiccator [18]. After measurement of the moisture content, samples of the initial product and fried products were subjected to Soxhlet extraction by hexane to measure the oil content [18]. The results of moisture content and oil content were used to compare the quality of fried products. The temperature profile was measured by wire thermocouples at 0 , $3,6,9$, and $12 \mathrm{~mm}$ from the center of the fried products. The temperature results showed the effect on moisture and oil content. Scanning electron microscopy (SEM) $(\times 75)$ observed the changes in crust structure and pore size..

\section{RESUlTS AND DISCUSSION}

\section{A. Moisture Loss and Oil uptake in Fish Tofu}

Oil content is the most important parameter for healthier food and low fat products are preferred by consumers [14]. Several studies reported on the escaping of water and frying oil absorption into the structure of fried food. Surface oil was absorbed and penetrated into porous areas after removing the fried food from deep heated oil because the moisture content vaporized during the immersion period [14]. Oil absorption was related to moisture content [8]. Frying temperature, frying time, food composition, porosity, pretreatment, and oil quality had effects on oil absorption [2].

This experiment showed that the mean (SD) initial fat content was $0.91 \pm 0.07 \mathrm{~g} / \mathrm{g}$ solid (Fig. 2). Statistical analysis showed that 1) the oil content in either condition was not significantly different $(\mathrm{p}<0.05)$ at the initial frying time up to $60 \mathrm{sec}, 2)$ the levels of oil content at frying times greater than $60 \mathrm{sec}$ were significantly different $(\mathrm{p}<0.05)$ between the two frying conditions, and 3 ) the results of the moisture content were significantly different $(\mathrm{p}<0.05)$ between the atmospheric frying and vacuum frying conditions.

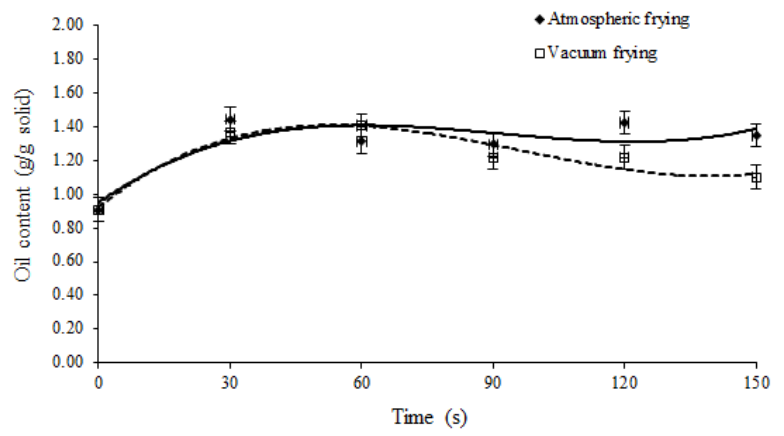

and surface oil flowed into the product at the end of the process and at the pressurization step in the vacuum frying process [5]. The final oil uptake at $150 \mathrm{sec}$ in the vacuum frying condition was lower than the final oil absorption at 150 $\mathrm{sec}$ in the atmospheric frying condition. 


\section{B. Temperature Change of Fish Tofu}

During frying time, heat transferred from the oil to the surface of the product by convection and towards the center by conduction and as the temperature increased to the boiling point the water evaporated [17]. The rate of temperature change was rapid at the beginning. The rate of temperature change in the atmospheric frying process was greater than in the vacuum frying process. The boiling point of water was lower during the vacuum frying time $[3,9,10,14]$. The temperatures that needed to be at the boiling points of water at the center of the products at $15 \mathrm{kPa}, 20 \mathrm{kPa}$, and $25 \mathrm{kPa}$ were $55.5^{\circ} \mathrm{C}, 62.3{ }^{\circ} \mathrm{C}$, and $67.6{ }^{\circ} \mathrm{C}$, respectively. For atmospheric frying condition, the boiling point was $100{ }^{\circ} \mathrm{C}$ at $101.3 \mathrm{kPa}$ [3]. For this experiment at $150 \mathrm{sec}$ following industrial frying time conditions, the water temperature at the center of the products reached $61.3{ }^{\circ} \mathrm{C}$ at $150 \mathrm{sec}$ in the vacuum frying condition and $85.0{ }^{\circ} \mathrm{C}$ at $150 \mathrm{sec}$ in the atmospheric frying condition (Fig. 3). The statistical analysis showed significant differences $(\mathrm{p}<0.05)$ in the temperature of the fried products between atmospheric frying and vacuum frying. Several studies have shown that high temperature caused structural change and loss of moisture, especially in the atmospheric frying process [5].

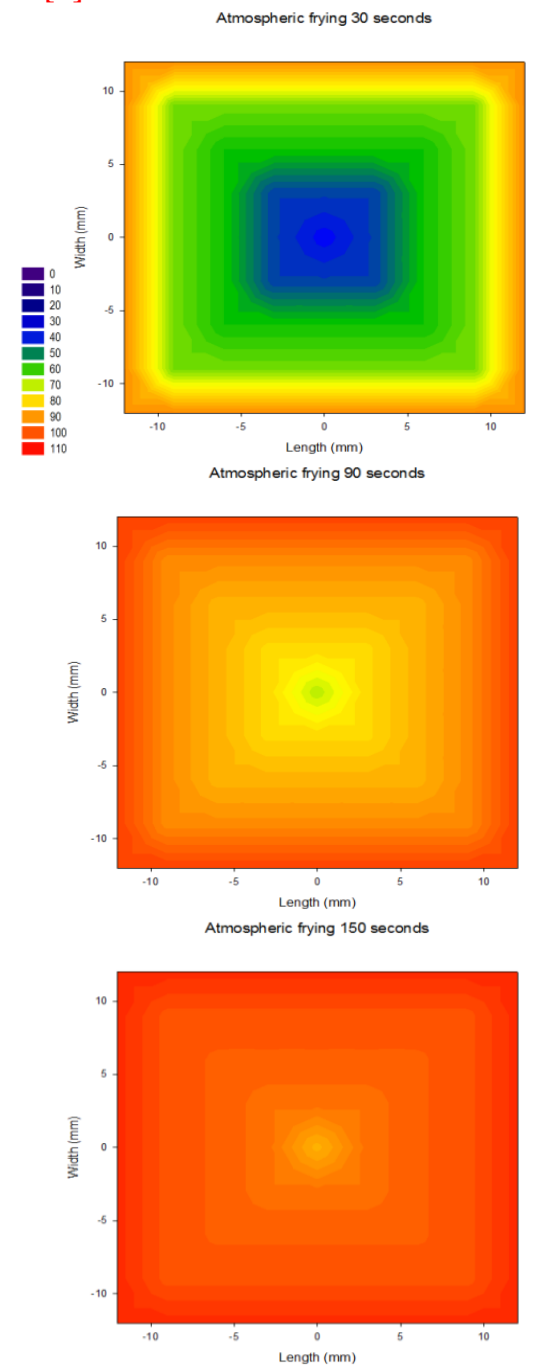

a. Atmospheric frying condition
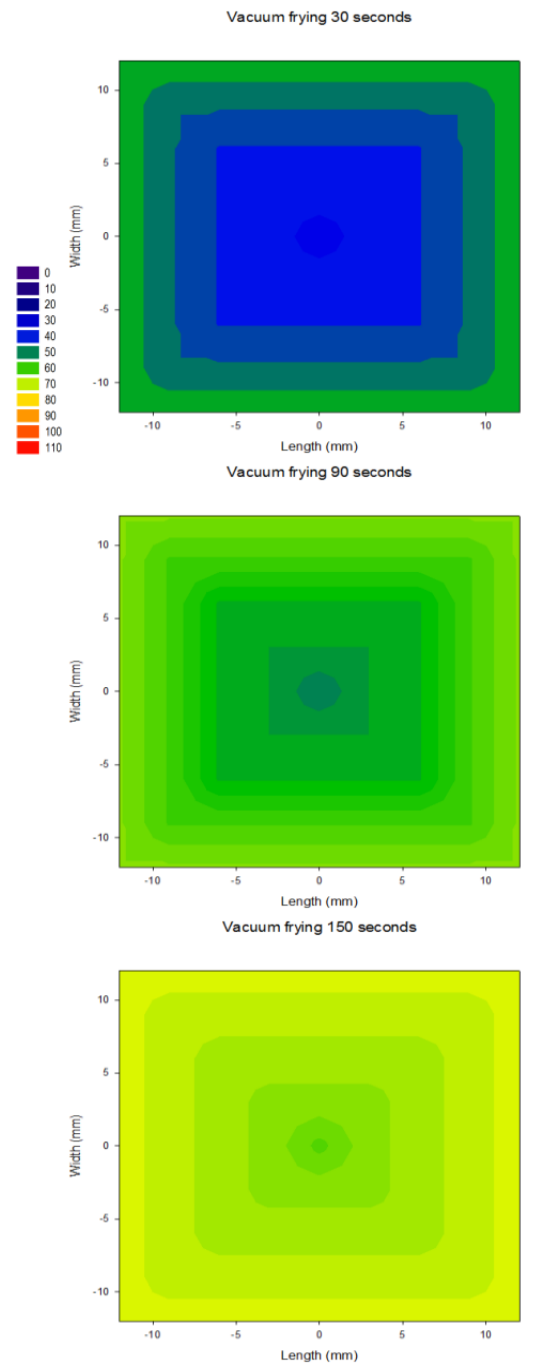

b. Vacuum frying condition

Fig. 3: Two-dimensional plot of temperature profile for fish tofu

\section{Structure and Crust}

High oil temperature was important for the development of a solid crust and surface properties of the product especially in the atmospheric frying condition [8]. During the frying time, the microstructure changed and it was affected by heat transfer and dehydration as the water was released and the cells shrunk and their walls became wrinkled and convoluted [17]. The pore size and microstructure of the crust affected the transport of water and oil in the foods [12, 14]. Water loss was obstructed by the semi-permeable crust barrier [1].

Several studies showed that the crust microstructure plays a critical role in oil absorption both in atmospheric and vacuum fried food and a linear relationship of porosity and final oil content in fried potato slices was found [15]. Oil adhered and entered into the damaged areas [9]. Moreover, the product expanded due to the fast rate of water loss during crust formation [17]. In addition, oil permeability and diffusivity were affected due to the changes in pore size during crust formation, collapsing, and expanding [7].

Cross-sections were used to observe porosity on the surface by scanning electron microscopy (SEM) [8, 9]. In this 
research, pore size characterization of fish tofu was performed under three conditions (Fig. 4). Steamed fish tofu was prepared from the defrost condition $\left(4^{\circ} \mathrm{C}\right)$. The atmospheric frying condition was $165^{\circ} \mathrm{C}$ for $150 \mathrm{sec}$ and the vacuum frying condition was $120{ }^{\circ} \mathrm{C}$ at $21 \mathrm{kPa}$ for $150 \mathrm{sec}$. Surimi protein was formed by hot steam in the forming period. A fine porous structure is common in steamed fish tofu. Different conditions presented different pore size characterizations. Pressure and temperature in the frying conditions had an important influence on pore characterization of fish tofu.

The frying temperature in some studies did not significantly affect oil uptake but other studies showed contrary results [12]. High temperature caused the product surface to become rigid quickly [17]. In this case, the results could be due to the higher frying temperature that had an effect on the crust, and skin surface collapsing, a change in porosity related to moisture and oil transport phenomena, and the final moisture and oil content of atmospheric and vacuum frying conditions. The results could be due to the change in pore size and crust structure which had an effect on oil absorption of fried fish tofu.

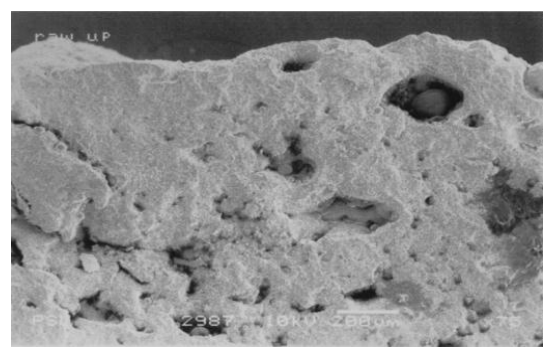

a) Defrost condition

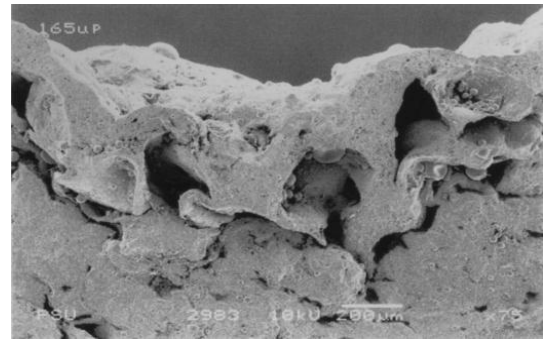

b) Atmospheric frying condition

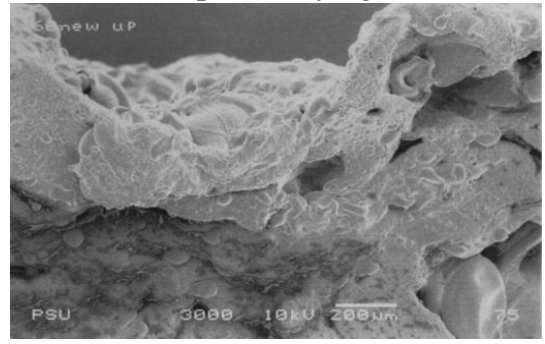

c) Vacuum frying condition

Fig. 4: Pore size and crust microstructure of fish tofu (modified [19])

\section{CONCLUSIONS}

The effect of a high frying temperature changed the solid crust and caused a collapse of surface properties. The results indicate a concern for the microstructure destruction and collapsing of the surface which resulted in a decrease in the moisture content and an increase in the oil content. The vacuum frying condition can reduce the oil content during the frying period. The results provide an alternative beneficial way to obtain low oil content of foods.

\section{ACKNOWLEDGEMENTS}

The authors would like to express their sincere thanks to the Department of Chemical Engineering, Faculty of Engineering, Prince of Songkla University, Thailand for their experimentation and laboratory analysis support. We would like to thank the Pacific Fish Processing Co., Ltd. for providing the fish tofu and soybean oil.

\section{REFERENCES}

[1] J. Mir-Bel, R. Oria, and M. L. Salvador, "Influence of temperature on heat transfer coefficient during moderate vacuum deep-fat frying," Journal of Food Engineering, vol. 113, pp. 167-176, 2012.

http://dx.doi.org/10.1016/j.jfoodeng.2012.06.009

[2] R. Sothornvit, "Edible coating and post-frying centrifuge step effect on quality of vacuum fried banana chips," Journal of Food Engineering, vol. 107, pp. 319-325, 2011.

http://dx.doi.org/10.1016/j.jfoodeng.2011.07.010

[3] A. Andrés-Bello, P. García-Segovia, and J. Martinez-Monzó, "Vacuum frying process of gilthead sea bream (Sparus aurata) fillets," Innovative Food Science and Emerging Technologies, vol. 11, pp. 630-636, 2010. http://dx.doi.org/10.1016/j.ifset.2010.06.002

[4] E. Troncoso, F. Pedreschi, and R. N. Zúñiga, "Comparative study of physical and sensory properties of pre-treated potato slices during vacuum and atmospheric frying," LWT - Food Science and Technology, vol. 42, pp. 187-195, 2009.

[5] M. Mariscal, and P. Bouchon, "Comparison between atmospheric and vacuum frying of apple slices," Food Chemistry, vol. 107, pp. 15611569, 2008.

http://dx.doi.org/10.1016/j.foodchem.2007.09.031

[6] V. Dueik, P. Robert, and P. Bouchon, "Vacuum frying reduces oil uptake and improves the quality parameters," Food Chemistry, vol. 119, pp. 1143-1149, 2010.

http://dx.doi.org/10.1016/j.foodchem.2009.08.027

[7] P. Warning, A. Dhall, D. Mitrea, and A. K. Datta, "Porous media based model for deep-fat vacuum frying potato chips," Journal of Food Engineering, vol. 110, pp. 428-440, 2012.

http://dx.doi.org/10.1016/j.jfoodeng.2011.12.024

[8] J. Garayo, and R. Moreira, "Vacuum frying of potato chips," Journal of Food Engineering, vol. 55, pp. 181-191, 2002. http://dx.doi.org/10.1016/S0260-8774(02)00062-6

[9] S. L. Shyu, and L. S. Hwang, "Effects of processing conditions on the quality of vacuum fried apple chips," Food Research International, vol. 34, pp. 133-142, 2001.

http://dx.doi.org/10.1016/S0963-9969(00)00141-1

[10] S. L. Shyu, L. B. Hau, and L. S. Hwang, "Effect of processing conditions on the quality of vacuum-fried carrot chips," Journal of the Science of Food and Agriculture, vol. 85, pp. 1903-1908, 2005. http://dx.doi.org/10.1002/jsfa.2195

[11] P. F. Da Silva, and R. G. Moreira, "Vacuum frying of high-quality fruit and vegetable-based snacks," LWT-Food Science and Technology, vol. 41, pp. 1758-1767, 2008.

http://dx.doi.org/10.1016/j.lwt.2008.01.016 
[12] E. Troncoso, and F. Pedreschi, "Modeling water loss and oil uptake during vacuum frying of pre-treated potato slices," $L W T$ - Food Science and Technology, vol. 42, pp. 1164-1173, 2009.

[13] R. Yamsaengsung, T. Ariyapuchai, and K. Prasertsit, "Effects of vacuum frying on structural changes of bananas," Journal of Food Engineering, vol. 106, pp. 298-305, 2011.

http://dx.doi.org/10.1016/j.jfoodeng.2011.05.016

[14] V. Dueik, M. C. Moreno, and P. Bouchon, "Microstructural approach to understand oil adsorption during vacuum and atmospheric frying," Journal of Food Engineering, vol. 111, pp. 528-536, 2012.

http://dx.doi.org/10.1016/j.jfoodeng.2012.02.027

[15] M. J. Crosa, V. Skerl, M. Cadenazzi, L. Olazábal, R. Silva, G. Suburú, and M. Torres, "Change produced in oils during vacuum and traditional frying of potato chips," Food Chemistry, vol. 146, pp. 603-607, 2014. http://dx.doi.org/10.1016/j.foodchem.2013.08.132

[16] T. Ophithakorn, and R. Yamsaengsung, "Oil Absorption during Vacuum frying of fish tofu," in Proc. 2003 PSU-UNS International Conf., 2003.

[17] C. V. Yagua, and R. G. Moreira, "Physical and thermal properties of potato chips during vacuum frying," Journal of Food Engineering, vol. 104, pp. 272-28, 2011.

http://dx.doi.org/10.1016/j.jfoodeng.2010.12.018

[18] Official methods of analysis, $15^{\text {th }}$ ed., Association of Official Analytical Chemists, Washington, DC, 1990.

[19] T. Ophithakorn, "Oil Absorption during Vacuum frying of fish tofu," M.S. thesis, Dept. Chem. Eng., Prince of Songkla Univ., Songkhla, Thailand, 2004. 